\section{References}

1 Gaull G E, Rassin D K, Struman J A. Letter: Pyridoxine dependency in homocystinuria. Lancet 1968; ii: 1302.

2 Reid D W J, Campbell D J, Yakymyshyn I Y. Quantitative amino acids in amniotic fluid and maternal plasma in early and late pregnancy. Am J Obstet Gynecol 1971 ; 111 : 251-8.

3 Mabry C C, Denniston J C, Coldwell J F. Mental retardation in children of phenylketonuric mothers. $N$ Engl J Med 1966; 275: 1331-6.

4 Stevenson R E, Huntley C C. Congenital malformations in offspring of phenylketonuric mothers. Pediatrics 1967; 40: $33-45$.
5 Rassin D K, Fleisher L D, Muir A, Desnick R J, Gaull $\mathrm{G}$ E. Fetal tissue amino acid concentrations in argininesuccinic aciduria and in maternal homocystinuria. Clin Chim Acta 1979; 94: 101-8.

- Bittle A H, Carson N A J. Tissue culture techniques as an aid to prenatal diagnosis and genetic counselling in homocystinuria. J Med Genet 1973; 10: 120-1.

Correspondence to Dr T W Kurczynski, Department of Pediatrics, Case Western Reserve University, Cleveland, Ohio 44106, USA.

\title{
Asymptomatic bacteriuria in healthy preterm babies
}

\author{
M MONCRIEFF, M BAMFORD, J BENSON, AND JANE BODDEN
}

John Radcliffe Hospital, Oxford

SUMMARY Urine was cultured from 151 healthy preterm babies. If the initial bag specimen grew more than 50000 organisms $/ \mathrm{ml}$, a second bag specimen was cultured. After two positive bag specimens a suprapubicurine wascultured. Significant bacteriuria was excluded on the basis of one or two bag specimens in $90 \%$ of the babies. Suprapubic urine was sterile in a further 11 babies. Four babies with positive bag specimens were unfortunately not completely investigated: 2 had mixed growths and 2 had pure growths of 100000 organisms/ml. As we and others consider that bacteriuria can only be diagnosed on a suprapubic sample of urine the incidence of proved infection in our series was zero. If both the babies with a pure growth of 100000 organisms $/ \mathrm{ml}$ had true bacteriuria, the incidence would rise to $1 \cdot 3 \%$. In view of the difficulties in obtaining clean urine samples in preterm babies and as the incidence of bacteriuria is so low, we do not recommend that healthy preterm babies be screened for bacteriuria.

Numerous surveys have shown that between 1 and $2 \%$ of girls have asymptomatic bacteriuria, and many already have renal scars present at the time of diagnosis. This applies to schoolchildren, ${ }^{1}$ school entrants, ${ }^{2}$ and to younger children and infants after the newborn period. ${ }^{3}$ It is likely therefore that asymptomatic bacteriuria occurs in the newborn period in at least some of these children, and treatment then might prevent the subsequent development of renal damage. However, Edelman et al. $^{4}$ found no clear case of asymptomatic bacteriuria in 836 healthy term newborn babies, although in preterm babies, who are particularly liable to infection, an appreciable incidence has been reported, varying from $2 \cdot 4^{4}$ to $25 \%{ }^{5}$ In view of this large difference in incidence we, too, carried out a survey to detect asymptomatic bacteriuria in preterm babies, and we assess the usefulness of such screening.

\section{Methods}

Urine was collected from babies of less than 37 weeks' gestation, who were not acutely ill, and who were not receiving antibiotics. Gestation was estimated from the beginning of the mother's last menstrual period, and confirmed by the modified Farr score. ${ }^{6}$

The baby's genitalia were washed with tap water, dried with a sterile cotton-wool swab, and a urine collecting bag was applied. The bag was inspected every 15 minutes. As soon as urine was passed it was transferred to a sterile bottle and taken to the laboratory. Most samples were examined immediately, but some were refrigerated overnight and examined the next morning. A standard calibrated loop, which delivers $2 \mu 1$, was used to inoculate blood agar and MacConkey's agar. The colonies were counted after overnight incubation.

Initially we planned that if the first urine contained $>10000$ organisms $/ \mathrm{ml}$ a second bag specimen would be cultured a few days later. If two bag specimens grew $>10000$ organisms $/ \mathrm{ml}$ a third specimen would be obtained soon afterwards by suprapubic bladder puncture (SP urine). However 18 of the first 30 bag 
specimens had counts $>10000$ organisms $/ \mathrm{ml}$ (ten were between 10000 and 50000 , five between 50000 and 100000 , and three $>100000$ ), and in each the SP urine was sterile on culture. After this, and for purposes of analysis, we decided to investigate further only those patients in whom the first bag urine grew $>50000$ organisms $/ \mathrm{ml}$; a further bag specimen was obtained as soon as possible and, if this grew $>50000$ organisms $/ \mathrm{ml}$, SP urine was cultured.

\section{Results}

Urine was obtained from 151 preterm babies (73 boys and 78 girls) whose birthweights ranged between 1120 and $3200 \mathrm{~g}$ with gestations between 29 and 37 weeks. 120 specimens were from babies aged 5-14 days, 25 from babies 15-21 days, and 6 from babies aged 21-28 days. 149 were bag specimens and 115 of these had counts of 50000 organisms $/ \mathrm{ml}$ or less. Two specimens were obtained by suprapubic bladder puncture and both were sterile on culture. 34 bag specimens had growths $>50000$. In 24 of these further bag specimens were obtained and in 21 culture yielded 50000 organisms or less. In 7 of the 34 babies retested, a second specimen was obtained by suprapubic bladder puncture and each one was sterile on culture. In the remaining 3 babies a second specimen was not obtained. In the 3 babies, in whom the second bag urine grew $>50000$ organisms $/ \mathrm{ml}$, SP urine was obtained from 2 and was

Table 1 Results of urine culture in 151 preterm babies
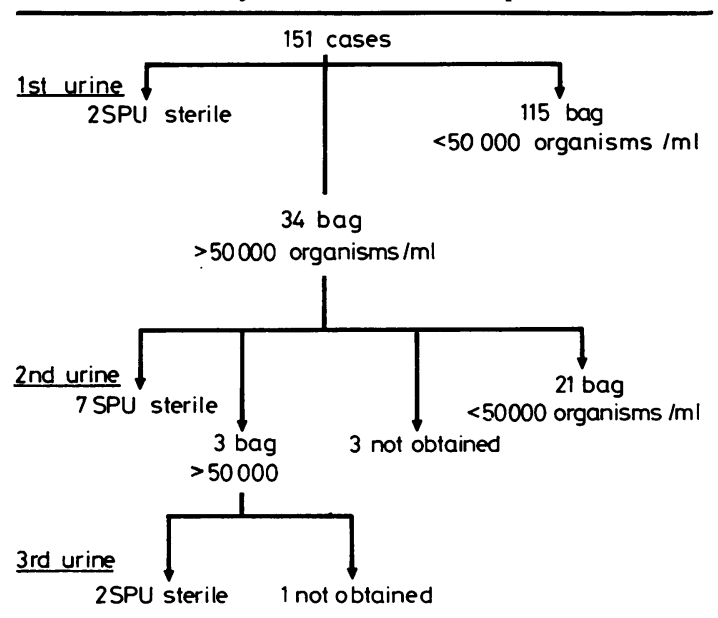

Total SPU sterile $=11 \quad$ Bag $>50000$ organisms $/ \mathrm{ml}=4$ Bag $<50000$ organisms $/ \mathrm{ml}=136$
Table 2 Details of urine culture in 4 babies incompletely investigated

\begin{tabular}{lll}
\hline Case & 1st specimen & 2nd specimen \\
\hline 1 & $100000 \mathrm{~S}$. albus & Not obtained \\
2 & 100000 coliforms & Not obtained \\
3 & 105000 coliforms, & 125000 coliforms, \\
& 4 types & 3 types \\
4 & $50000 S$. albus & Not obtained \\
& 6000 coliforms & \\
\hline
\end{tabular}

sterile on culture, but in the third no further specimen was obtained. These results are summarised in Table 1.

In the whole series, 147 babies did not have bacteriuria as defined. Four babies, who were incompletely investigated, had growths in bag specimens $>50000$ organisms $/ \mathrm{ml} ; 2$ were mixed growths and 2 were single organisms. Details of these specimens are given in Table 2.

\section{Discussion}

Initially, it had been decided to regard a bacterial count $<10000 / \mathrm{ml}$ as negative and to obtain a further specimen if the count was above this, with a SP urine culture after two positive bag specimens. However, 18 of the first 30 babies studied had bacterial counts $>10000 / \mathrm{ml}, 8$ of these being $>50000 / \mathrm{ml}$, yet SP urine was sterile in all 18 . Similarly Edelman et $a .^{4}$ found that SP urine was nearly always sterile, even though a previous bag specimen had grown $>10000$ organisms $/ \mathrm{ml}$ (the actual bacterial count was not specified in these cases). We felt it would be unethical to proceed with a study which necessitated obtaining SP urine in at least half the babies. We therefore adopted the same criterion as Davies et $_{\text {al }}{ }^{3}$ and decided to investigate further only babies who had bacterial counts $>50000 / \mathrm{ml}$, and to regard counts below this level as negative.

Our results show that $77 \%$ of the initial bag specimens were negative, and $87 \%$ of repeat specimens were negative. Thus on the basis of bag specimens significant bacteriuria was excluded in $90 \%$ of the babies. SP urine was sterile in 11 babies, leaving $4(2.6 \%)$ babies who were incompletely investigated. Two of these had mixed growths, and we consider were most unlikely to have significant bacteriuria. Two babies with pure growths of 100000 organisms $/ \mathrm{ml}$ were unfortunately not investigated further, and might have had significant bacteriuria. In the absence of SP urine culture neither can be regarded as having a proved infection, ${ }^{4}$ and so the incidence of proved infection in our series is zero; if both these babies had significant bacteriuria, the incidence would rise to $1 \cdot 3 \%$. 
Earlier studies, such as that by Hodgman et al. ${ }^{5}$ in which the diagnosis was not based on SP urine culture would not now be accepted. In studies in which the diagnosis of bacteriuria was based on SP urine culture, Pendarvis et al. ${ }^{7}$ found $10 \%$ of preterm babies who had weekly cultures had bacteriuria, Zies et al. ${ }^{8}$ found $5.6 \%$ of preterm babies had bacteriuria, and Edelman et al. ${ }^{4}$ found bacteriuria in $2 \cdot 4-3 \cdot 4 \%$ of preterm babies. The incidence in our series which may well be zero is much lower. This may be due to the fact that in our unit ill babies and babies suspected, or at risk, of developing infection are treated promptly with antibiotics and were excluded from the study.

We feel that as it is often difficult to obtain a clean urine specimen in a small baby and as the incidence of asymptomatic bacteriuria in healthy preterm infants is so low, routine screening for this is not justified. In order to detect asymptomatic bacteriuria before renal damage has occurred, babies need to be screened after the newborn period. We also endorse the statement by Edelman et al. ${ }^{4}$ that a bag specimen can only show the absence of bacteriuria; confirmation of bacteriuria must always be based on culture of SP urine.

We thank Dr Baum, Dr Bower, Dr Pickering, and Professor Tizard for permission to study their patients, Miss Townsend and her staff for collecting the urine specimens, and Mr Day for technical help.

\section{References}

1 McLachlan M S F, Meller S T, Verrier Jones E R, et al. Urinary tract in schoolgirls with covert bacteriuria. Arch Dis Child 1975; 50: 253-8.

2 Savage D C L, Wilson M I, Ross E M, Fee W M. Asymptomatic bacteriuria in girl entrants to Dundee primary schools. Br Med J 1969; iii : 75-80.

3 Davies J M, Gibson G L, Littlewood J M, Meadow S R. Prevalence of bacteriuria in infants and pre-school children. Lancet 1974 ; ii: 7-10.

4 Edelman C M, Jr, Ogwo J E, Fine B P, Martinez A B. The prevalence of bacteriuria in full term and premature newborn infants. J Pediatr 1973; 82: 125-32.

5 Hodgman J E, Schwartz A, Thrupp L D. Bacteriuria in the premature infant (abstract). Pediatr Res 1967; 1: 303.

- Davies P A, Robinson R J, Scopes J W, Tizard J P M, Wigglesworth $\mathrm{J}$ S. Medical care of newborn babies. Assessment of gestational age. Clinics in Developmental Medicine Nos 44/45. London: Heinemann Medical, 1972: 91-5.

7 Pendarvis B C, Jr, Wenzl J E, Chitwood L. Bacteriuria in premature infants detected by aspiration, cultures. Pediatr News 1970; 4: 33.

8 Zies L, Ramirez J, Jannach J R. Incidence of bacteriuria in the premature infant as determined by suprapubic aspiration. J Fla Med Assoc 1968; 55: 452-4.

Correspondence to $\mathrm{Dr} M$ Moncrieff, Department of Paediatrics, John Radcliffe Hospital, Headington, Oxford OX3 9DU.

\section{Pituitary cretinism in two sisters}

\section{HITOSHI KOHNO, NORIAKI WATANABE, MASAAKI OOTSUKA, MAKOTO KAJIWARA, NAGAHIDE GOHYA}

Department of Paediatrics, Kyushu University School of Medicine, Fukuoka, Japan

SUMMARY Two sisters with cretinism are reported. Each showed low levels of serum triiodothyronine, thyroxine, and thyroid-stimulating hormone (TSH). In the elder sister, serum TSH did not increase after administration of thyrotropin-releasing hormone. We conclude that cretinism in these 2 sisters was due to TSH deficiency. This is the second report of 'familial' pituitary cretinism (TSH-deficient congenital hypothyroidism).

Congenital pituitary hypothyroidism is thought to be rare. 15 cases have been reported, ${ }^{1-11}$ nearly all of them sporadic. In each the diagnosis was confirmed by low serum thyroid-stimulating hormone (TSH) being determined by radioimmunoassay. Among these cases was one familial case: that of 2 sisters with cretinism due to TSH deficiency. ${ }^{4}$ This is the second report of familial pituitary cretinism.

\section{Case report}

The 2 children were among 6 of 2nd-cousin parents (Fig. 1). Their brothers were reported to be growing and developing normally and their mother was clinically euthyroid with normal concentrations of serum triiodothyronine (T3), thyroxine (T4), and TSH. 